\title{
Facilitating epistemological access by developing students experiences of undergraduate research
}

\author{
Vahed, Anisa ${ }^{a}$ and Singh, Shalini ${ }^{b}$ \\ ${ }^{a}$ Department of Dental Sciences, Dental Techology programme, Durban University of \\ Technology, South Africa, ${ }^{b}$ Department of Operations and Quality Management, Durban \\ University of Technology, South Africa
}

\begin{abstract}
Quality supervision at undergraduate level provides the impetus for students to complete their research projects successfully and to progress to higher levels of postgraduate studies. Yet very little work has been documented on developing students' experiences of undergraduate research in preparing lecturers to empower students for postgraduate studies. Proponents of undergraduate research claim that quality supervision enables students to engage with their own research project; develop higher-order research related skills such as critical thinking; to plan and organise their research work in real-world settings; and to develop problem-solving and analytical skills. Fundamentally these capabilities can be applied to professional practice, thereby enabling students to be better prepared for a knowledgebased economy, which is a national imperative in the higher education research agenda. This paper assessed the epistemological access of undergraduate students in terms of developing their research potential. A case study research design within a qualitative framework was used. Census sampling was used $(n=20)$. Data were collected by means of focus groups and students' reflective reports, which were thematically analysed. Overall, the salient features of this paper showed that students' described the teaching of research as the theory and the supervision of research as the practice, which assisted them in developing their skills, abilities and dispositions to make informed decisions and to self-manage their undergraduate research projects and practice.
\end{abstract}

Keywords: epistemological access; undergraduate research; Quality Management; Dental Technology 


\section{Introduction}

Several authors (Armstrong \& Shanker, 1983; Council on Higher Education, 2013; Howitt, Wilson, Wilson, \& Roberts, 2010; Lopatto, 2004; Reynolds \& Thompson, 2011; SpronkenSmith, Mirosa, \& Darrou, 2013) allude to undergraduate research being the bedrock of postgraduate research, particularly in terms of ensuring that there is a supply of future researchers to be recruited and trained for a more demanding postgraduate trajectory. They suggest that undergraduate research can be measured in terms of three broad categories, namely: institutional context; nature and quality of supervision; and characteristics of the research student. While a vast body of literature exists on the students' experiences of postgraduate research (Bitzer \& Albertyn, 2011; Buttery, Richter, \& Filho, 2005; Council on Higher Education, 2009; Lee, 2008, 2012), less evidence exists about developing the students experiences of engaging with undergraduate research in preparing lecturers to empower students for postgraduate studies. This is significant in the context of the increasing proportion of undergraduate students from previously disadvantaged backgrounds with limited experience of undertaking independent research work (South African Survey of Student Engagment, 2010). Arguably, the research project at an undergraduate level is more likely to be the first time a student is expected to adopt an autonomous role as a researcher, which is different from their previous experiences where their work is driven mainly by their lecturer. The challenge of framing a research idea and the successive re-drafting is truly new for undergraduate students, especially as they are expected to make the transition to an independent mode of study.

\section{Aim of the study}

To assess epistemological access to develop students' experiences of undergraduate research. It is worth noting that this study responds to the key strategic drivers of the Durban University of Technology (DUT), where this study was undertaken is to be a student-centred and an engaged institution by seeking new knowledge through its research and teaching. In particular, the study seeks to understand the students experiences and to build research into the undergraduate curriculum (Durban Univerisity of Technology, 2015)

\section{Research Methodology}

Higher education scholars (Healey, Jenkins, \& Lea, 2014; Healey, Jordan, Pell, \& Short, 2010; Howitt et al., 2010; Lee, 2008; Mainhard, van der Rijst, van Tartwijk, \& Wubbels, 2009; Nulty, Kiley, \& Meyers, 2009) indicate that embedding research knowledge and skills within the undergraduate curriculum strengthens students' undergraduate research experiences. This study therefore used a case study research strategy (Remenyi, 2013) to aid an in-depth exploration into developing student experiences of undergraduate research. 
This approach is associated with qualitative research as it aims to holistically "understand the case in depth, and in its natural setting, recognizing the complexity and its context" (Punch, 2014, p. 120). The participants involved were the Degree of Bachelor of Technology (B Tech) students from two different programmes at DUT in Durban, South Africa. In particular, the 2014 students $(n=10)$ registered for the subject Project 401, which is part of the B Tech in Quality within the Operations and Quality Management programme in the Faculty of Management Sciences and the 2015 students $(n=10)$ registered for the subject Research Methods and Techniques I, which is part of the B Tech in Dental Technology programme in the Faculty of Health Sciences. Permission to collect data was obtained from the Institutional Research Ethics Committee (IREC). Ethical clearance and permission to conduct the study was obtained from DUTs Institutional Research Ethics Committee (IREC Number: 102/15). Informed consent was obtained from the participants prior to commencement of the interviews. The focus group interviews were audio recorded, and anonymity and confidentiality were maintained by using pseudonyms. Interview data were inductively analysed using the principles of thematic analysis. Students' feedback on research training workshops, together with their research output, maintained the trustworthiness of the data.

\section{Findings and Discussion}

There were primarily two recurring themes, namely: the various teaching methods helped develop students' understandings of research (Figure 1); and the positive attributes of the supervisors contributed to a constructive and effective learning environment (Figure 2).

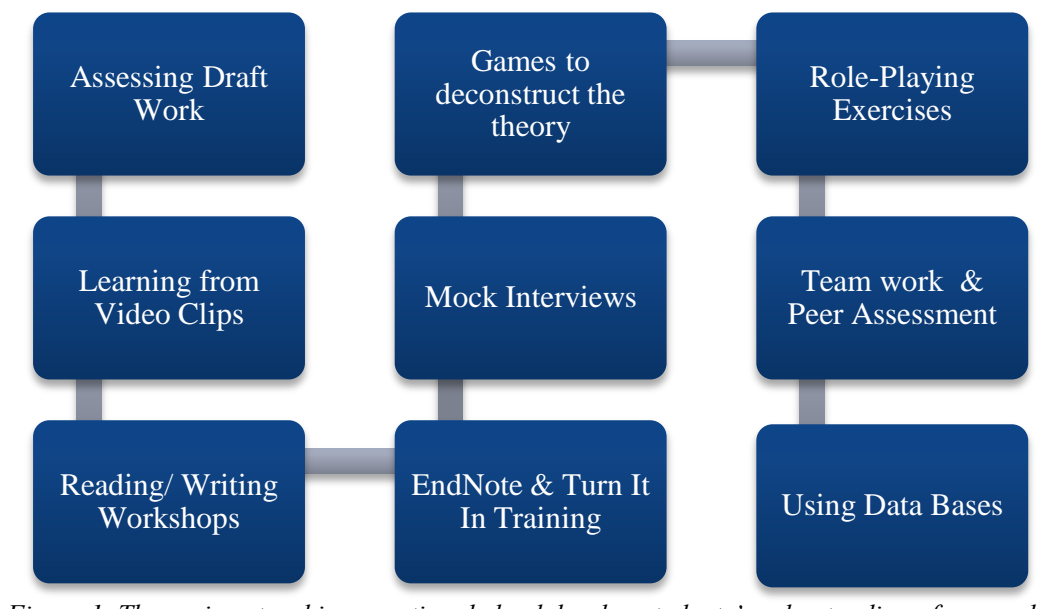

Figure 1. The various teaching practices helped develop students' understanding of research.

Generally, undergraduate research is the first level at which students' access and acquire knowledge on the various research discourses, particularly towards becoming a researcher. Students positively conveyed that "...teaching is like the theory part and the supervising is 
like the practical." Essentially, the various teaching methods enabled students to acquire their learners that is the theoretical 'know-why' knowledge to access and acquire the research discourse. Supervision, by contrast, is the license to apply the practical 'knowhow' knowledge of research. Equally important, students declared that "the lecturer showed support for all the students' during data collection by accompanying everyone to their different facilities, which is just caring". Another critical point that deserves mentioning is that "...she encouraged us and said, no, you can do it... even over e-mails she encourages us to still carry on when I wanted to give up." They also prominently emphasized that the lecturer was "...always available ... going to the extent of setting all these devices and technology up so that they can assist the student, that just shows me that the person is approachable." In terms of good supervision, she encouraged us "... to push our boundaries and raise the standards...", thereby enabling them to develop skills to critically evaluate and apply evidence-based arguments in their research reports. Evidently, students' interest and active engagement with their individual research projects was significantly shaped by the positive attributes of their research supervisors. These findings are consistent with Azila-Gbettor, Mensah, and Kwodjo (2015) and Woolderink, Putnik, van der Boom, and Klabbers (2015).

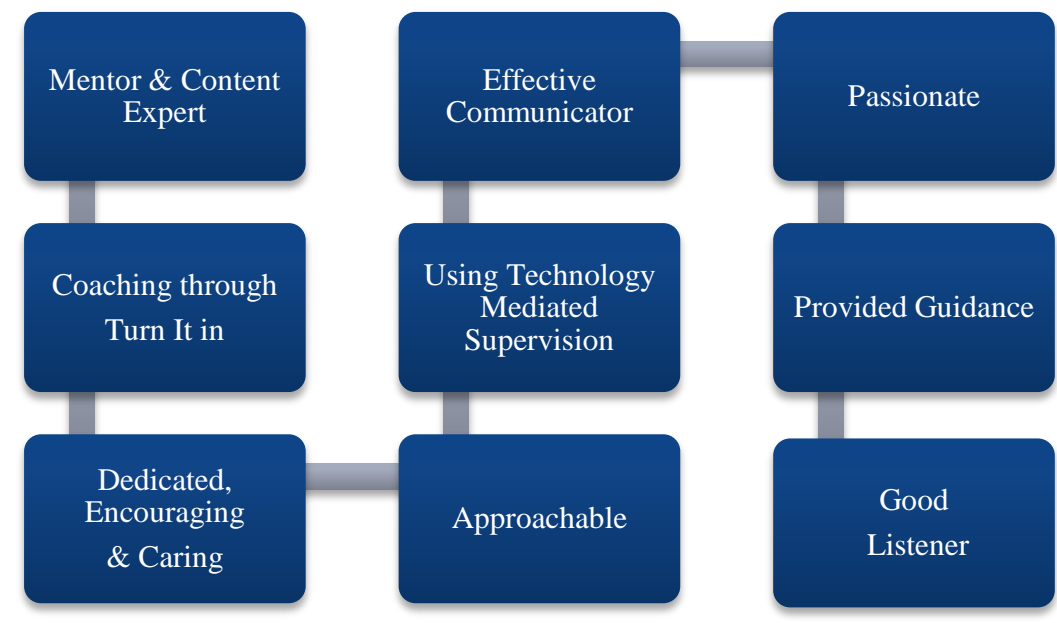

Figure 2. Positive attributes of the supervisors contributed to a constructive leaning milieu

Interestingly, students recommended that the teaching styles presented in Figure 1 "...be introduced in diploma years as it will greatly prepare the student for what to expect at a BTech level and will also motivate them to further their studies to a postgraduate level." This adds support to the Quality Enhancement project that aims to move DUT to become a student centred university through the transformation of teaching and learning and the promotion of quality enhancement (Durban Univerisity of Technology, 2015; Sattar \& 
Cooke, 2014). This aligns with the South African higher education agenda of preparing graduates for a more knowledge-intensive economy (The Presidency: Republic Of South Africa, 2012). Some of the students also critically pointed out that having joint supervisors was discouraging "...because one was with you $100 \%$ of the time and while the other was there $50 \%$ of the time...". This will be considered in the future supervision of undergraduate research projects. Finally, students' unanimously expressed their gratitude to their "...supervisor for her continuous commitment and encouragement and the training that she given us all and all the efforts that she's made...you've actually opened our eyes to a whole new world of reading reports and understanding that stuff".

\section{Conclusion}

The improved understandings of students' reported experiences have positively impacted on the development of two undergraduate modules for the new four year Bachelor of Health Sciences degree in Dental Technology. Particularly, the modules Introduction to the Principles and Practices of Research (Level 3) and Fundamental Principles and Practices of Research Design and Methodology (Level 4). In terms of the Bachelor of Quality degree students developed their knowledge in the modules Project (Level 4) and Continual Quality Improvement (Level 4). Further research to legitimise students' experiences of undergraduate research is yet to be conducted through the sociological lens of the Legitimation Code Theory (Maton, 2014), specifically the dimension of Semantics.

\section{References}

Armstrong, M., \& Shanker, V. (1983). The supervision of undergraduate research: Student perceptions of the supervisor role. Studies in Higher Education, 8(2), 177-183. doi:10.1080/03075078312331379044

Azila-Gbettor, E. M., Mensah, C., \& Kwodjo, S. M. (2015). Challenges of Writing dissertations: Perceptual differences between students and supervisors in a Ghanian Polytechnic. International Journal of Education and Practice, 3(4), 182-198.

Bitzer, E. M., \& Albertyn, R. M. (2011). Alternative approaches to postgraduate supervision: A planning tool to facilitate supervisory processes. South African Journal of Higher Education, 25(5), 874-888.

Buttery, E. A., Richter, E. M., \& Filho, W. L. (2005). An overview of the elements that influence efficiency in postgraduate supervisory practice arrangements. International Journal of Educational Management, 19(1), 7-26. doi:doi:10.1108/09513540510574920

Council on Higher Education. (2009). Postgraduate Studies in South Africa: A Statistical Profile Centre for Research on Science and Technology (Ed.) Retrieved from http://www.che.ac.za

Council on Higher Education. (2013). A proposal for undergraduate curriculum reform in South Africa: The case for a flexible curriculum structure. Pretoria: CHE Press. 
Durban Univerisity of Technology. (2015). DUT Strategic Plan 2015-2019: Towards Relevance, Responsiveness and Resilience. Durban Univerisity of Technology. Durban. Retrieved from www.dut.ac.za

Healey, M., Jenkins, A., \& Lea, J. (2014). Developing research-based curricula in collegebased higher education T. H. E. Academy (Ed.) Retrieved from https://www.heacademy.ac.uk/system/files/resources/developing_researchbased_curricula_in_cbhe_14.pdf

Healey, M., Jordan, F., Pell, B., \& Short, C. (2010). The research-teaching nexus: a case study of students' awareness, experiences and perceptions of research. Innovations in Education and Teaching International, 47(2), 235-246. doi:10.1080/14703291003718968

Howitt, S., Wilson, A., Wilson, K., \& Roberts, P. (2010). 'Please remember we are not all brilliant': undergraduates' experiences of an elite, research- intensive degree at a research- intensive university. Higher Education Research \& Development, 29(4), 405420. doi:10.1080/07294361003601883

Lee, A. (2008). How are doctoral students supervised? Concepts of doctoral research supervision. Studies in Higher Education, 33(33), 267-281.

Lee, A. (2012). Successful Research Supervision-Advising students doing research. New York: Routledge.

Lopatto, D. (2004). Survey of Undergraduate Research Experiences (SURE): First Findings. Cell Biology Education, 3(4), 270-277. doi:10.1187/cbe.04-07-0045

Mainhard, T., van der Rijst, R., van Tartwijk, J., \& Wubbels, T. (2009). A model for the supervisor-doctoral student relationship. Higher Education, 58(359-373).

Maton, K. (2014). Knowledge and Knowers: Towards a realist sociology of education. London, UK: Routledge.

Nulty, D., Kiley, M., \& Meyers, N. (2009). Promoting and recognising excellence in the supervision of research students: an evidence- based framework. Assessment \& Evaluation in Higher Education, 34(6), 693-707. doi:10.1080/02602930802474193

Punch, K. F. (2014). Introduction to Social Research: Quantitative \& Qualitative Approaches (3rd ed.). London: SAGE Publications Ltd.

Remenyi, D. (2013). Case Study Research: The Quick Guide Series (Second ed.). United Kingdom: Academic Conferences and Publishing International Limited.

Reynolds, J. A., \& Thompson, R. J., Jr. (2011). Want to improve undergraduate thesis writing? Engage students and their faculty readers in scientific peer review. CBE Life Sci Educ, 10(2), 209-215. doi:10.1187/cbe.10-10-0127

Sattar, K., \& Cooke, L. (2014). A position paper: Conceptualising the quality assurance of graduate attributes at the Durban University of Technology. Durban University of Technology. Durban. Retrieved from http://staffportal/CQPA/Graduate\%20Attributes/Position\%20paper\%20approved\%20by $\% 20$ Senate\%2027\%20August\%202014.pdf

South African Survey of Student Engagment. (2010). Institutional Report 2010: Durban University of Technology. Retrieved from Durban: http://sasse.ufs.ac.za 
Spronken-Smith, R., Mirosa, R., \& Darrou, M. (2013). 'Learning is an endless journey for anyone': undergraduate awareness, experiences and perceptions of the research culture in a research-intensive university. Higher Education Research \& Development, 33(2), 355-371. doi:10.1080/07294360.2013.832169

The Presidency: Republic Of South Africa. (2012). Executive Summary - National Development Plan 2030 - Our future - make it work. Pretoria: South African Government Retrieved from http://www.gov.za/issues/national-development-plan2030.

Woolderink, M., Putnik, K., van der Boom, H., \& Klabbers, G. (2015). The Voice of PhD Candidates and $\mathrm{PhD}$ Supervisors. A Qualitative Exploratory Study amongst $\mathrm{PhD}$ candidates and supervisors to evaluate the relational aspects of $\mathrm{PhD}$ Supervision in the Netherlands. International Journal of Doctoral Studies, 10, 215-235. Retrieved from http://ijds.org/Volume10/IJDSv10p217-235Woolderink0852.pdf 